\title{
CHRONIC HEPATITIS B
}

\author{
Vanja Ničković ${ }^{1}$, Radoslav Katanić ${ }^{2}$, Nataša Katanić ${ }^{2}$ \\ Ilija Kocić3
}

\begin{abstract}
Hepatitis B virus is a primarily hepatotropic virus, causing both acute and chronic hepatitis ( $\mathrm{CHB})$. Primary chronic hepatitis $\mathrm{B}$ is most commonly a self-limited disease with complete recovery within 2-3 months since the onset of the disease. It is believed that $2 / 3$ of the world population has been infected with hepatitis $B$ virus at some point during their lifetime.

According to the WHO reports, the incidence of HBV infection is decreasing due to the introduction of mandatory hepatitis B immunization. However, about 400 million people will develop chronic hepatitis $B$. More than million people die every year due to chronic HBV infections, liver cirrhosis and/or hepatocellular carcinoma (HCC). It means that the hepatitis $B$ virus infection is a major global health problem.

Timely diagnosis and adequate treatment significantly slow down the course and progression of chronic hepatitis $B$.
\end{abstract}

Acta Medica Medianae 2017;56(4):50-60.

Key words: hepatitis B virus, pathogenesis, clinical manifestation, immunization, diagnosis, treatment, chronic hepatitis $B$

\author{
${ }^{1}$ Clinical-Hospital Center Priština, Srbija \\ ${ }^{2}$ University of Priština, Faculty of medicine in Kosovska \\ Mitrovica, Serbia \\ ${ }^{3}$ University of Nis, Faculty of medicine, Nis, Serbia \\ Contact: Vanja Ničković \\ Bulevar Nemanjića 77/9, Niš, Serbia \\ e-mail: vanja.nickovic@gmail.com
}

\section{Introduction}

Hepatitis B virus is a primarily hepatotropic virus, causing both acute and chronic hepatitis (CHB). Primary chronic hepatitis B virus (HBV) infection is most commonly a self-limited disease with a complete recovery within 2-3 months since the onset of the disease. However, 5-10\% of primary HBV patients may develop persistent (chronic) infection (1).

According to the World Health Organization (WHO), about 400 million people ( $5 \%$ of the world population) are chronically infected. About 15$40 \%$ of patients with chronic HBV infection will develop liver cirrhosis, liver failure or hepatocelIular carcinoma (HCC). More than a million people die every year due to chronic HBV infections and/or HCC, so the hepatitis B virus infection is a major global health problem (2).

Hepatitis B virus is found in $25-45 \%$ of HCC patients. The incidence of $\mathrm{HCC}$ has been progressively increasing worldwide and it is the fifth most common malignancy in humans worldwide, with lethal outcome in 300.000-500.000 people per year. There is a significant population of patients with end-stage liver disease due to HBV and the ultimate cure for them is liver transplantation. At this moment, these patients represent 5-10\% of all patients who require liver transplantation (3).

According to the WHO reports, the incidence of $\mathrm{HBV}$ infection is decreasing due to introduction of mandatory hepatitis B immunization. However, there is still a high frequency of HBV infected persons. It is believed that $2 / 3$ of the world population has been infected with hepatitis B virus at some point during their lifetime. As for our country, it is estimated that more than $2 \%$ of population have chronic HBV infection. It should be emphasized that almost $1 \%$ of pregnant women in Belgrade have chronic HBV infection (1).

Structure and characteristics of hepatitis B
virus

Hepatitis B virus is a member of the Hepadna virus family. It is the only hepatotropic DNA virus. Hepatitis $B$ virus is a complex structure. Hepatitis B virus or Dane particle has a spherical structure with a diameter of $42 \mathrm{~nm}$. Viral particles with a coat and a core are complete and infectious. Viral particles with a coat, but without a core, are not infectious and they are found in circulation in spherical and tubular forms (Figure 1). The virus is composed of an outer coat and a nucleocapsid core. The coat is composed of proteins, lipids and carbohydrates. The main compo- 
nent of the coat is HBsAg. The nucleocapsid contains $\mathrm{HBCAg}, \mathrm{HBeAg}$ and DNA genome covalently

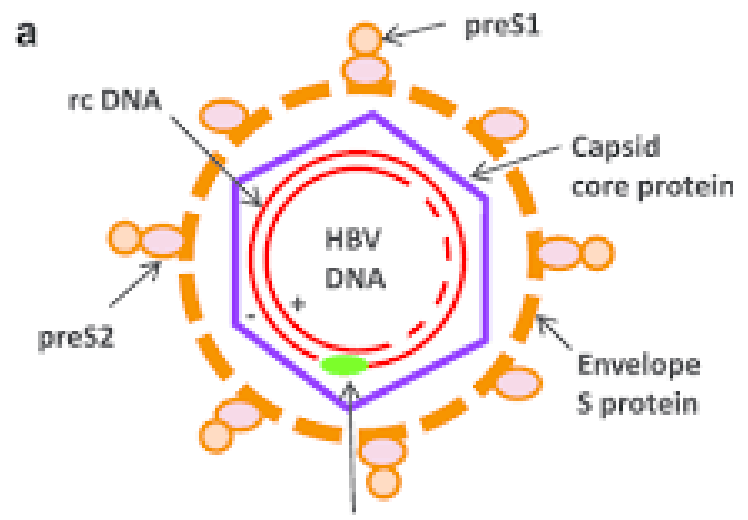

b
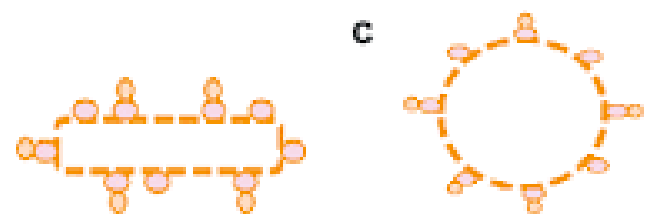

Figure 1. Infectious and non-infectious particles of hepatitis $B$ virus

linked by 2 DNA enzymes, polymerase and protein kinase.

HBV genome consists of four genes (regions) with partially overlapping open reading frames- S, C, P and X. The genome includes both structural component coding genes and regulatory components (promoters, enhancers), as well as the components for virus replication (DR1 and DR2- direct repeats) (Figure 2).

HBV genome codes several polypeptides: viral DNA polymerase, albumin receptors and

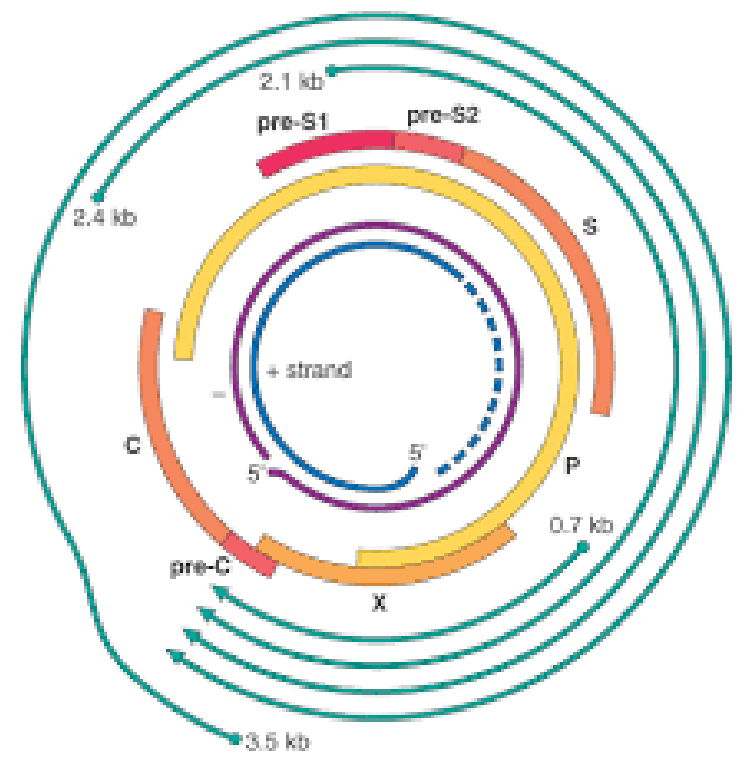

Figure 2. Genome and translation hepatitis $B$ virus structural antigens (HBsAg, $\mathrm{HBcAg}$ and $\mathrm{HBeAg}$ ).
The $\mathrm{S}$ region consists of pre-S and $\mathrm{S}$ genes. Pre-S gene consists of two sub-regions: pre-S1 and pre-S2. Pre-S1/preS2/S genes encode HBsAg, precore/core gene encodes structural proteins ( $\mathrm{HBCAg}$ and $\mathrm{HBeAg}$ ), polymerase $\mathrm{P}$ gen DNA K polymerase, and $X$ gene encodes HBX protein.

In the pre-S region there are several initiation codons to start nucleotide sequence reading, that may continue in the $\mathrm{S}$ region. The translation product of pre-S2 and $\mathrm{S}$ genetic sequence is preS2/S or MS (middle sized) polypeptide. The translation product of pre-S1/preS2/S gene sequence is LS (large sized) polypeptide. A product of the $S$ gene is SS (small sized) protein. MS, LS and SS proteins are viral envelope proteins. MS polypeptide initiates HBsAg secretion. A portion of MS proteins functions as a receptor for binding HBV to hepatocytes, by binding to human albumins. LS polypeptide acts as an inhibitor of $\mathrm{HBsAg}$ secretion. A product of the $\mathrm{S}$ gene is the major HBsAg polypeptide.

The core region is composed of precore/core genes that encode two proteins, longer $\mathrm{HBeAg}$ and shorter HBcAg. The core gene contains two initiation codons. When the translation begins from the first start codon, $\mathrm{HBeAg}$ is yielded, but when it begins at the second start codon, core protein $\mathrm{HBcAg}$ is yielded. $\mathrm{HBcAg}$ is the major structural nucleocapsid protein. The $X$ gene encodes HBxAg. $\mathrm{HBXAg}$ has multiple roles: it stimulates virus gene expression, contributes to HBV replication and integration of the viral genome in the host chromosome.

Polymerase $\mathrm{P}$ gene comprises $80 \%$ of HBV genome. The $\mathrm{P}$ gene encodes DNA polymerase, an enzyme that plays a role in viral replication (4).

In patients infected with hepatitis B virus, about 107 nucleotides are mis-incorporated into the viral genome during its replication due to repair system inefficiency. In this way, altered viral forms or variant genotypes and viral mutants are formed (5).

Within HBV $5-10 \%$ genomic sequences, there are differences in $10 \%$ of nucleotides. Ten different HBV genotypes have been registered. Genotypes are designated by capital letters from A to J. Different genotypes show different geographical distribution: genotype $A$ is common in the USA and in Northwestern Europe, genotypes B and $C$ in Asia, genotype $D$ in Mediterranean countries, Middle East and India, genotype $\mathrm{E}$ in west Africa (6).

It is reported that patients in Serbia are predominantly infected by genotype $D(86 \%)$ and genotype A (14\%). Impact of these genotypes on the disease course, response to therapy, and disease outcome are pointed out as well. It has been shown that patients with acute HBV infection caused by genotypes $A$ and $D$ more frequently present transition to chronic infection (1). 


\section{Epidemiology of HBV infection}

Significant differences in the prevalence of HBV infection have an impact on the onset of the disease and routes of infection transmission. In high prevalence areas, the infection is most commonly spread from an infected mother to her child at birth - perinatal transmission, postnatally or during early childhood. Transmission at the time of delivery is the consequence of mixing of fetal and maternal blood or swallowing of maternal blood and excretions by the infant. Perinatal transmission mostly results in chronic infection because neonates have an immature immune system. If the mother is $\mathrm{HBeAg}$ positive, with high levels of viremia, up to $90 \%$ of newborns will be infected. However, if the mother's HBeAg status is negative, only $10-20 \%$ of infants will be infected (7). It should be stressed that almost every 4th person infected in childhood develops liver cirrhosis and primary liver tumor later in life. In areas with low HBV endemicity, sexual contact is the predominant route of transmission, and the infection is more common in adulthood.

Hepatitis B virus is highly infectious and easily transmitted. It can be found in the blood, saliva, semen, vaginal secretion and in menstrual blood as well. The virus is rather resistant in an environment, where it can survive up to 7 days. Hepatitis $B$ virus is 10 times more infectious than hepatitis $C$ virus and about 100 times more infectious than HIV. Patients with $\mathrm{CHB}$ infection are the virus reservoir, thus posing a risk for the transmission of the infection (8).

The disease can be transmitted in two ways - horizontally and vertically. Horizontal route means sexual and percutaneous transmission of the infection. Sexual routes are the dominant modes of transmission in highly developed countries. Percutaneous transmission is the predominant mode of transmission in moderately developed countries.

The infection can be transmitted by using the same syringe among injection drug users, sharing personal hygiene accessories, and by tattooing, acupuncture, and cosmetic procedures, as well $(9,10)$.

Nosocomial infection occurs while unsafely handling the needles and other medical instruments contaminated with blood and blood derivatives. The possibility of virus transmission is high, since only $0.00004 \mathrm{ml}$ of infected person's blood contain enough viruses to cause an infection. The risk of infection transmission from health care workers to patients during invasive medical procedures depends on HBsAg status of medical staff and viremia levels of HBV DNA in the serum. It is believed that a high viremia level is that of $3 \times 104$ copies/ml in the serum (11).

On the other hand, medical professionals are among those at a high risk of infection (3-4 times higher than that in general population).

The risk of infection after an injury with contaminated surgical instruments or after needle- stick injury depends on whether contaminated blood is $\mathrm{HBsAg}$ and/or $\mathrm{HBeAg}$ positive. If a patient is $\mathrm{HBsAg}$ and $\mathrm{HBeAg}$ positive, the probability of getting the infection is around $62 \%$. If a patient is HBsAg positive and $\mathrm{HBeAg}$ negative, the chances to contract the infection are markedly lower (up to $20-40 \%)(12)$.

\section{Pathogenesis of chronic hepatitis B}

The majority of studies suggest that hepatitis $B$ virus is not directly cytopathic to hepatocytes. The outcome of HBV infection is determined by the immune response of every single individual. Cellular and humoral immune responses play a role in virus elimination. Cellular immune response has a key role in hepatitis $B$ pathogenesis. Persistence of HBV infection, namely the development of acute into CHB infec-tion is the result of poor cellular response (13). The weakness of CTLs and weakness of Th- 1 type CD4-T lymphocytes does not result in the lysis of infected hepatocytes, and liver necrosis and inflammation are thus maintained.

CTLs and helper $T$ lymphocytes have a role in HBV elimination. CD4-T lymphocytes have a leading role in immune response regulation. Based on their cytokine production, CD4-T lymphocytes are classified into two groups designated Th1 ( $\mathrm{T}$ helper 1) and Th2 (T-helper 2). The outcome of the immune response is determined by the balance between Th1 and Th2 lymphocytes. Th- 1 cells secret cytokines IL-2, IFN-alpha and Iymphotoxin. These cytokines induce cellular immune response. Th-2 lymphocytes produce IL-4, IL-5 and IL-10, which promote humoral response. Domination of Th1-type CD4-T lymphocytes favours cellular immune response and along with $C T L$ has a role in the lysis of infected lymphocytes. Th1-type CD4-T lymphocytes and CTL are responsible for virus elimination in acute HBV infection (14).

CD4-T lymphocytes secrete interferons which have multiple roles: they increase the expression of HLA on the hepatocytes, activate intracellular enzymes (that inhibit viral protein synthesis) and increase NK (natural killer) cell activity (15).

The CTL response to envelope antigens and nucleocapsid, as well as to viral DNA polymerase, is polyclonal. Coat antigens form a complex with HLA system class I. CTL cells lyse infected hepatocytes, directly binding to HBsAg complex and HLA system I on the surface of the hepatocytes, thus making small apoptotic bodies. CTL cells lyse infected hepatocytes indirectly via cytokines. The effect of CTL cells is enhanced by CD4-T Iymphocytes. CD4-T lymphocytes bind to nucleotide antigens $\mathrm{HBCAg}$ and $\mathrm{HBeAg}$ that are in complex with HLA system class II and lyse them by cytokine effects. Macrophages are also involved in the lysis of infected hepatocytes by cytokine effect or by the process of phagocytosis. Humoral immune response in acute hepatitis is involved in the formation of antibodies which form complexes with 
free viral particles and remove them from the circulation (16).

By the domination of Th2 type CD4-T lymphocytes, cytokines are secreted, inducing humoral immune response. Humoral immune response plays a role in the occurrence of extrahepatic manifestations. Immune complex depositions are responsible for extrahepatic manifestations. Immune complexes are composed of HBV antigens (HBsAg, HBeAg, HbcAg), autoantigens (liver anti-gens, albumins, bacterial antigens), and IgM and IgG class antibodies.

Immune complexes adhere to the complement and deposit in the basement membrane of the vessel walls, renal glomeruli, nerves, myocardium and pancreas causing vasculitis, polyarteritis nodosa, glomerulonephritis, neuropathy - GuillanBarre syndrome, autoimmune anemias, thrombocytopenia, myocarditis and pancreatitis (17).

Hepatitis B virus replication in chronic hepatitis $B$

In case of a deficient host immune response, the virus propagates, persists in hepatocytes and infects new hepatocytes. The disease is selfsustained and chronic liver inflammation or chronic hepatitis $\mathrm{B}(\mathrm{CHB})$ infection develops. The course of chronic HBV infection consists of two phases: replicative and non-replicative (integrative) ones. The mechanism of HBV replication is analogous to retroviral replication (based on reverse transcription). Infection of hepatocytes with
HBV begins with virus attachments to hepatocyte membrane receptors, followed by virus penetration into the hepatocyte cytoplasm. In a hepatocyte, the virus DNA may be found in free replicative form or integrated into the hepatocyte genome. DNA integrated into the genome has oncogenic potential and induces the process of mutagenesis, namely the changes in gene expression. Accumulation of genetic damage contributes to HBV progression (Figure 3) (18).

In a constantly infected hepatocyte, nuclei contain between 30 and 50 copies of covalently closed circular DNA (cccDNA). A mature virion can be recycled in the hepatocyte nucleus, where it is converted into new copies of cccDNK. In the replication phase, cccDNA functions in the hepatocyte nucleus as a template for pregenomic RNA production. The replication phase typically lasts from 2 to 7 years. In this phase, HBV DNA is in a free form in the hepatocyte nucleus, and the virus constantly replicates. Reactivation of viral replication from persistent cccDNA is the main source of manifest hepatitis in immunodeficient patients and is the resource for new viral particle synthesis (19).

The replication phase is followed by nonreplication phase of $\mathrm{HBV}$ infection. Integration of viral DNA into chromosomes occurs in the hepatocyte nucleus. Integrated ccc DNA cannot function as a template for pregenomic viral RNA. In nonreplication phase, HBV replication markers disappear from the serum (HBV DNA, HBeAg) and from the liver ( $\mathrm{HBcAg})$. Seroconversion of $\mathrm{HBeAg}$ into anti $\mathrm{HBe}$ antibodies then occurs. However, $\mathrm{HBsAg}$

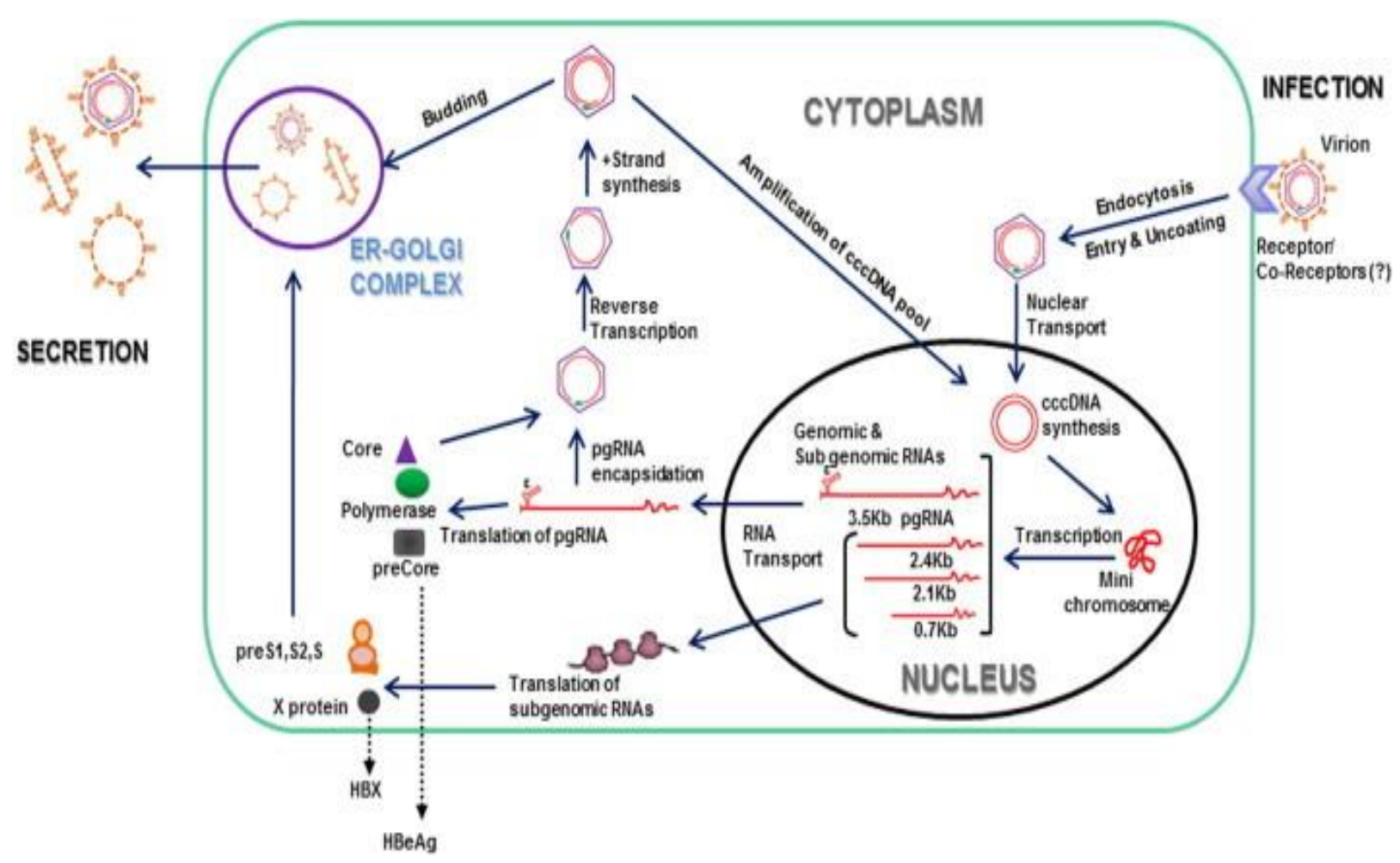

Figure 3. Replicative cycle of hepatitis B virus in the hepatocyte 
conversion is rare. HBsAg is still produced from the ccc DNA genome of hepatocyte nuclei. This phase correlates with clinical disease remission. It is characterized by low infectivity, progression from chronically active to chronically persistent hepatitis or inactive cirrhosis (20).

Exacerbation of HBV replication and reactivation of HBV infection can be stimulated by immunosuppressive therapy, organ transplantation and by superinfection by other hepatotropic viruses as well (HCV, HDV, HGV) (21).

\section{Stages of chronic hepatitis B}

Chronic HBV infection is a dynamic process divided into 5 phases.

The first phase is the immune tolerant phase. It is characterized by $\mathrm{HBeAg}$ in the serum, high viremia (high levels of HBV DNA in the blood), normal aminotransferase levels, and minimum liver necroinflammation. According to some studies, $\mathrm{HBeAg}$ is believed to be a tolerance factor, meaning that it could affect T-cell nonreactivity. This phase is longer in perinatally or early childhood infected patients. It can last for decades (10-30 years). Due to high levels of viremia, these patients are highly contagious. The immune tolerant phase does not necessarily have to be present.

The second phase is an immune-active or immune-eliminatory phase. It is characterized by an increased transaminase activity (more than 5 times) preceded by elevation of viremia, that is HBV DNA. In this phase, the activity of cytotoxic T-lymphocytes (CTL cells), which lyse the infected hepatocytes, is high. It is accompanied by a pronounced liver necroinflammation. After a rise in HBV DNA and transaminase, their levels progressively decrease. Spontaneous conversion, the loss of $\mathrm{HBeAg}$ and gain of anti-HBe antibodies may also occur in this phase. In most patients, HBeAg seroconversion marks the transition from chronic to 'healthy carrier' (inactive CHB) form.

The third phase is inactive phase or immune-control phase. It is characterized by the maintenance of $\mathrm{HBsAg}, \mathrm{HBeAg}-$ negative and-HBe antibodies positive, low serum HBV DNA levels (< $2000 \mathrm{IU} / \mathrm{ml}$ ) and normal serum aminotransferase levels. The results of immunological control of the infection suggest a favourable long-term outcome. The risk of cirrhosis or HCC development is very low. The survival rate after 25 years in these patients is about $25 \%$.

The fourth phase is reactivation phase. It is a late phase in the natural course of chronic HBV. Reactivation follows seroconversion from $\mathrm{HBeAg}$ to anti-HBe antibodies in immunodeficiency conditions and in patients undergoing immunosuppressive therapy. It is characterized by periodical reactivation of the disease, fluctuating HBV DNA levels, as well as fluctuating aminotransaminases. In this phase, $\mathrm{CHB}$ is an active disease with a high risk of fibrosis progression and the development of cirrhosis and HCC (22).

The fifth phase is HBsAg negative phase. It develops after HBsAg loss and is characterized by low-level HBV replication, with blood HBV DNA levels of $<200 \mathrm{IU} / \mathrm{ml}$. Loss of HBsAg is associated with a more favourable outcome and reduced risk of disease progression.

There are two forms of $\mathrm{CHB}$ infection: hepatitis $B$ antigen (HBeAg) positive and hepatitis $B$ antigen ( $\mathrm{HbeAg})$ negative $(23,24)$.

\section{HBeAg positive chronic hepatitis B}

This form of hepatitis develops due to HBV infection with wild-type virus and is characteristic for early $\mathrm{CHB}$ phase. The course of an HBeAg positive infection depends mostly on the age at which primary infection is acquired. It occurs more frequently at a younger age, namely in persons who acquired HBV infection in childhood. A perinatal infection after $10-30$ years results in moderate or severe $\mathrm{CHB}$. Adults infected later in life present moderate to severe HBeAg positive infection.

Spontaneous seroconversion (loss of $\mathrm{HBeAg}$ and presence of anti-HBe antibodies in the serum), occurs in $50-70 \%$ of patients. Predictive factors of spontaneous seroconversion are female gender and high serum transaminase levels.

In most patients, an $\mathrm{HBeAg}$ seroconversion marks the transition from chronic disease to a healthy carrier state. This phase of $\mathrm{CHB}$ is characterized by the presence of $\mathrm{HBsAg}$, anti-HBe antibodies and low or undetectable levels of viral replication (HBV DNA), as well as normal transaminase activity.

The prognosis of healthy carrier state is usually good. Reactivation of the disease occurs during immunodeficiency and after immunosuppressive therapy (corticotherapies, chemotherapies and immunotherapies) (25).

\section{$\mathrm{HBeAg}$ negative chronic hepatitis B}

This form of hepatitis is caused by a mutant form of $\mathrm{HBV}$. Mutation in the precore region creates a premature stop codon, causing the loss of $\mathrm{HBeAg}$ and resulting in premature termination of protein translation. This form of $\mathrm{CHB}$ occurs in the later phase of chronic HBV infection. It is characterized by unstable course, fluctuations in serum transaminases and HBV DNA levels. The patients with this form of hepatitis tend to be older males. The prognosis is poor and the patients are more likely to have rapid development and progression of fibrosis, development of cirrhosis and $\operatorname{HCC}(26,27)$.

\section{Clinical manifestation of chronic hepatitis B}

Chronic hepatitis $B$ is an insidious disease. Its course is mostly asymptomatic. It is detected accidentally on routine examinations by the findings of elevated transaminases in the blood, findings of HBsAg in voluntary blood donors' serum, as well as by blood testing after surgical interventions. About $30 \%$ of patients have nonspecific symptoms, such as exhaustion (most commonly), fatigue, dyspeptic syndrome (loss of 
appetite and nausea), dull epigastric pain and right subcostal pain, as well as muscular and joint pain.

Elevated temperature rarely occurs. Symptoms of the disease do not always correlate with the severity of liver damage. Most patients do not have anamnestic data about the preceding acute hepatitis. It is an indication that patients with mild, anicteric or asymptomatic form of acute hepatitis $B$ are at a higher risk of acquiring $\mathrm{CHB}$. It has been proven that in about $20 \%$ of patients infected with hepatitis $B$ virus the disease progresses into chronic form (28).

Physical findings of $\mathrm{CHB}$ are unspecific. Slightly enlarged and hard consistency liver is most commonly present, but icterus and splenomegaly are not so common. Intermittent or pronounced icterus, splenomegaly, hemorrhage, spider nevi, and ascites accompany an already present liver cirrhosis. In some patients with clinical presentation of $\mathrm{CHB}$, predominant extrahepatic manifestations include polyarteritis nodosa, glomerulonephritis, neuropathies, myocarditis, pancreatitis and some others.

The course of $\mathrm{CHB}$ depends on age, gender, mode of transmission (the amount of virus in the body), degree of virus replication and immune response of the host. Progression of $\mathrm{CHB}$ into liver cirrhosis and HCC depends on multiple factors, such as the time of acquiring primary infection, constant alcohol intake and smoking, exposure to alpha toxins, coinfections with other viruses (HDV, HCV, HIV), family history and pre-sence of other liver diseases as well (29).

\section{Diagnosis of chronic hepatitis B}

A combination of biochemical, serological and virological testing, along with histological findings on biopsy, is the most reliable approach in the diagnosis of $\mathrm{CHB}$.

Moderately elevated transaminase activity suggests that disease activity is in progress. Etiological diagnosis of HBV infection is established by detecting HBsAg in serum using the ELISA test. In most patients, HBeAg detection in the serum is required, as well as $\mathrm{HBCAg}$ in the liver tissue.

HBsAg appears a month and a half after the time of infection in the period of incubation, or 1-2 weeks before the first symptoms of the disease occur. In convalescent phase of self-limited hepatitis B, HBsAg slowly disappears by seroconversion into anti-HBs antibodies which are immunogenic and life-long.

Biochemically, persistence of elevated aminotransferase activity indicates a progression of acute into chronic hepatitis $B$ infection. Persistence of HBV DNA over 8 weeks, HBeAg more than 10 weeks and HBsAg longer than 6 months in the serum also suggest a progression of acute into $\mathrm{CHB}$. In $\mathrm{CHB}, \mathrm{HBsAg}$ quantitative test is significant for the introduction or discontinuation of therapy (30).

In most patients, continuous viral replication correlates with disease activity and is associated with necroinflammatory activity of the liver parenchyma (piecemeal and confluent bridging necrosis). Active $\mathrm{CHB}$ disease is characterized by high levels of HBV DNA and HBeAg in the serum and $\mathrm{HBCAg}$ in the liver (chronic active hepatitis) (31).

In non-replicative phase, disease remission is achieved either spontaneously or as the therapy effect. HBV DNA and $\mathrm{HBeAg}$ in the serum become undetectable and $\mathrm{HBeAg}$ seroconversion occurs. After that, most patients have an inactive phase of liver disease. They are often healthy carriers of HBsAg.

The presence of HBV DNA in the serum can be proved by HBV DNA sensitivity test, such as polymerization of nucleic acid (PCR) (32). The diagnosis of chronic infection course is primarily based on the detection of HBV DNA levels, as well as on application of serological tests to evaluate $\mathrm{HBeAg}$ seroconversion. HBsAg seroconversion is rarely achieved. The level of viremia during a chronic HBV infection is clearly disease phase related.

In the immune-tolerant phase, a high degree of viremia ( $>108$ copies/ml) is seen, as well as normal ALT activity. In the immune eliminatory phase the degree of viremia is between 105 and 109 copies/ml serum, with ALT elevation and signs of necroinflammatory damage on liver biopsy (33, 34). Histopathological findings (by way of immunochemical staining for $\mathrm{HBcAg}$ ) reveal the disease activity dependent degree of $\mathrm{HBcAg}$ (a marker of viral replication) expression in hepatocyte nucleus and cytoplasm. In inactive liver disease, HBcAg is diffusely present in the cytoplasm (vs focally in active liver disease) (35). The inactive phase is characterized by low viremia $(<105$ copies/ml) in the serum and by ALT level normalization.

Liver biopsy and histopathological finding is a reliable method to confirm the diagnosis and in disease progression monitoring. In acute hepatitis, histopathological findings show some conspicuous changes in the acinus and less conspicuous in the portal tract, with an intact limiting plate. In $\mathrm{CHB}$, changes are more pronounced in the portal tract and are periportally spread, disturbing the limiting plate between the portal area and lobules.

The aim of histopathological liver testing is to analyze the degree of necroinflammation and fibrosis. Such a developed system detects each structural change in the liver.

Gerber and Metavir current classifications of necroinflammation and fibrosis severity use a numerical scoring system to assess the changes that are quantitatively and qualitatively graded (36).

Necroinflammatory activities are numerically rated as follows:

A0- no activity

A1- mild activity

A2- moderate activity

A3- severe activity

The amount of fibrosis is assessed and rated according to the thickness of the septal connective tissue and surrounding portal involvement:

F0- no fibrosis

F1- mild portal fibrosis without septa 
F2- moderate portal fibrosis with few septa cirrhosis

F3- severe fibrosis, numerous septa without

F4-liver cirrhosis

\section{Chronic hepatitis B therapy}

The main goal of chronic HBV infection treatment is the suppression of viral replication and sustained immune control (SIC). SIC is obtained by way of replication marker decrease (HBV DNK $<2000 \mathrm{IU} / \mathrm{ml}$ or 104 copies/ml), HBeAg seroconversion and by reduction of transaminase levels within reference values. The desired endpoint of $\mathrm{CHB}$ therapy is to achieve undetectable viremia (CBV DNA $<10-15 \mathrm{IU} / \mathrm{ml}$ ), which is defined by a PCR test. Undetectable levels of HBV DNA increase the possibility of $\mathrm{HBe}$ seroconversion and HBsAg loss both in $\mathrm{HBeAg}$ positive and $\mathrm{HBeAg}$ negative patients. In this way, extrahepatic complications are prevented, the risk of cirrhosis and HCC development is reduced, and survival rate is improved. HBsAg loss is a marker of stable remission.

The National Institute of Health established the definition and criteria for $\mathrm{CHB}$ treatment in 2003, and a standardized approach to define a response to anti-viral therapy was adopted. The response was defined as biochemical response (normalization of serum ALT), virological response (decrease in serum HBV DNA or loss of HBeAg in HBeAg positive patients) and histological response (decrease in necroinflammatory score on liver biopsy by at least 2 points compared to the pretreatment score). A complete score involves the fulfillment of all three previous criteria. A response can be achieved during the treatment, at the end of the treatment, or 6-12 months after cessation of the therapy $(37,23)$.

Before the introduction of therapy, the factors that should be considered include the HBV DNA level, transaminase activity, level of necroinflammatory activity, level of fibrosis, patient's age, health status and availability of antiviral drugs.

Therapeutic approaches are different in relation to the form of hepatitis B ( $\mathrm{HBeAg}$ positive or $\mathrm{HBeAg}$ negative hepatitis forms). There are two treatment strategies for a $\mathrm{CHB}$ infection. The first one stimulates insufficient, but already activated host Th1 response that lyses the infected hepatocytes and the second is the one that suppresses viremia. The basis of immune therapy for $\mathrm{CHB}$ has been the use of interferon since the early 1960s (38). Interferon has immunomodulatory, antiviral and antiproliferative effects. Immunomodulatory effect includes the enhancement of cell immune response by CTL cell stimulation, activation of macrophages and NK cells, stimulation of CD4 Thelper cells, and increased density of HLA class I on the surface of infected hepatocytes.

In low viremia (HBV DNA <107copies/ml), Peg-interferon alpha-2a (PEG IFN alpha-2a) is the first line antiviral treatment for $\mathrm{HBeAg}$ positive hepatitis. The best effect of PEG IFN alpha-2a has been shown in genotypes $A$ and $B$ in younger patients. The combination of PEG ITN alpha-2a and lamivudine showed a higher response rate, but not a more durable posttreatment response.

The main advantages of interferon therapy are its finite duration, absence of resistance, longer duration of achieved therapeutic response and probability of HBsAg clearance. The level of HBsAg in serum correlates with the level of HBV cccDNA in hepatocytes. That is why serum HBsAg clearance is considered to be the best indicator of stable disease remission. PEG IFN alpha-2a is used at a dose of $180 \mu \mathrm{g}$ weekly for 48 weeks. However, interferon has certain limitations, such as insufficient viremia suppression (HBV DNA) and numerous side effects (neutropenia, thrombocytopenia, skin disorders, depression exacerbation, thyroid dysfunction, increased risk of insulin resistance and type 2 diabetes and exacerbation of autoimmune diseases) (39).

In patients with contraindications or without stable remission, the second choice for achieving remission is the application of another type of antiviral therapy, namely HBV inhibitor therapy classified into two groups: nucleotide analogues and nucleoside analogues. HBV inhibitors inhibit viral replication in two ways. They are incorporated into a DNA virus and inhibit DNA elongation or directly block reverse transcriptase. This group of nucleotide inhibitors includes lamivudine, which inhibits viral DNA synthesis by terminating the replication chain (40).

Lamivudine is used in the treatment of chronic active hepatitis $B$ in patients with compensated and decompensated liver and in patients undergoing liver transplantation for HBV infection. Lamivudine is well tolerated and is given at a dose of $100 \mathrm{mg}$ daily. Therapeutic effects are achieved after 6 months of therapy (loss of replication markers, ALT level normalization and reduction of necroinflammatory activity). However, a limitation is the reversal of HBV DNA level to the base level upon discontinuation of the therapy, accompanied by transaminase elevation. The treatment of patients with decompensated cirrhosis and HBV infection has shown significantly improved biochemical and histopathological findings. After liver transplantation in HBV infected patients, lamivudine demonstrated substantial suppression of HBV replication, thus preventing reinfection and rejection of the graft (41).

First line monotherapy tenofovir or entecavir is offered to patients with HBeAg positive hepatitis $B$ low viremia levels in whom $\mathrm{HBeAg}$ interferon conversion failed, to those who are HBeAg positive with moderate to severe viremia, and to patients with $\mathrm{HBeAg}$ negative hepatitis B low viremia. Entecavir and tenofovir are potent inhibitors of HBV replication with a high barrier of resistance.

Entecavir is substantially superior (30 to 2200 times) in achieving the inhibition of DNA replication in comparison to lamivudine. In patients with proved resistance to lamivudine, entecavir monotherapy is not recommended. Entecavir is given in the form of a tablet at a $0.5 \mathrm{mg}$ daily dose. It inhibits the transcription of negative chain and synthesis of positive chain viral DNA (42). 
The second group of HBV inhibitors are nucleotide analogues. They include two drugs, tenofovir and adefovir. They are in a triphosphate form, and cell phosphorylation is therefore not required. Both drugs have an impact on primary reverse transcription inhibition and viral minus DNA chain synthesis. Tenofovir is given orally at a dose of $245 \mathrm{mg}$ daily, it is well tolerated and is used for the treatment of active hepatitis with constant virus replication, constantly elevated ALT level and active histological inflammation and fibroses. It has a high resistance threshold during a 2-year treatment. Besides the antiviral effect, adefovir has an immunomodulatory effect as well and enhances the NK cell activities. It is effective in the treatment of HBV mutant forms, HBV wild forms and lamivudine resistant HBV. Its effectiveness has been proved in reducing cccDNA, and in virus replication in the biliary tree as well. Due to its potent suppression of viral replication, it is administered to patients in post-transplantation period to prevent graft reinfection and to those with compensated and decompensated cirrhosis with HBV infection. The dose is $10 \mathrm{mg}$ a day (43, 44).

A long-term nucleoside analogue treatment is applied in the cases when sustained virological response (SVR) is not achieved in patients with high pre-treatment levels (HBV DNA >108 copies $/ \mathrm{ml}$ ) in the presence of cirrhosis.

The therapy is discontinued in the absence of primary response (more common for adefovir) and a more potent suppressive drug is recommended (entecavir or tenofovir). In partial viral response (for lamivudine, telbivudine, adefovir), two strategies are employed: switching to a more potent drug (entecavir or tenofovir) or addition of a drug that does not show cross-resistance (adding tenofovir to lamivudine, orantecavir to adefovir).

However, if a virological breakthrough (antiviral drug resistance) occurs during the treatment of patients with high pre-treatment HBV DNA levels, or in previously untreated patients, a biochemical breakthrough follows and then a clinical breakthrough as well. The only efficient strategy in virological breakthrough is the addition of a second drug (salvage therapy - in case of lamivudine resistance tenofovir should be added, emtricitabine to tenofovir, tenofovir to entecavir, tenofovir to telbivudine). Combined therapy of potent suppressors of HBV DNA with high barrier for resistance development (most commonly entecavir and tenofovir) is applied in patients with compensated and decompensated cirrhosis, in patients with extrahepatic manifestations, at immunosuppressive therapy introduction, and before and after liver transplantation as well (1).

\section{Prevention of HBV infection}

Prevention of hepatitis B may be passive, active and combined. Passive protection involves the application of protective anti-HBs - hepatitis B surface antibody levels (Hepatitis B immunoglobulin-HBIG). Active protection means getting the vaccine (specific surface antigens, HBsAg) that elicits the synthesis of specific antibodies. Combined protection involves the application of both passive and active protection.

Nowadays, a genetically engineered and yeast-based second generation vaccine is used. The vaccine is administered to adults on a 3-dose schedule at 0,1 and 6 months since the first deltoid muscle intramuscular injection. The vaccination dose for adults is from $20 \mu \mathrm{g}$, and halfdose of adult vaccine is administered to infants. Immunosuppressed persons receive a higher-dose vaccine $(40 \mu \mathrm{g})$ given in a 4 -dose schedule at 0,1 , 2 and 12 months. A vaccinated person is considered protected if the level of anti-HBs antibodies in the serum is above $10 \mathrm{IU} / \mathrm{ml}$ after the third application. A protective anti-HBs antibody in immunocompetent persons is maintained for about 9 years.

A $\mathrm{HB}$ vaccine in combination with $\mathrm{HBIG}$ is applied in infants born from $\mathrm{HBsAg}$ and $\mathrm{HBeAg}$ positive mothers and in persons who are at direct risk of $\mathrm{HBV}$ infection (for example, needle stick contaminated with HBsAg positive blood, sexual contact with HBsAg positive persons, and so on). The HBIG dose is $0.06 \mathrm{ml} / \mathrm{kg}$ of the body mass, and in newborns $0.5 \mathrm{ml} / \mathrm{kg}$. In the aforementioned cases, passive protection should always be combined with the vaccine.

Infants born to $\mathrm{HBsAg}$ and $\mathrm{HBeAg}$ positive mothers should receive $0.5 \mathrm{ml}$ HBIG after birth without any delay (in the first two hours after birth) and the first vaccine dose within 7 days after birth.

The level of seroconversion (occurrence of anti-HBs antibodies in the serum) is achieved after the third vaccine in $96-100 \%$ of children and adolescents.

The latest third generation vaccine contains pre-S1, pre-S2 and $S$ antigenic components of HBsAg of both subtypes. It could be effective for those who need rapid and high-degree seroconversion (for example, in the prevention of HBV transmission from a mother to her child). Since the number of people with chronic HBV infection is globally high, continuous efforts in the prevention and immunization should be made in order to eradicate HBV (45-47).

\section{Conclusion}

In $\mathrm{CHB}$ infection, hepatitis B virus often mutates and its genome remains incorporated into the host hepatocyte genome, being often inaccessible to antiviral therapy effects. Once a person has been infected with this virus, it stays in the body forever. Hepatitis B virus has a strong oncogenic potential and out of all hepatotropic viruses it is the most common cause of HCC. Hepatitis $B$ virus is responsible for $2 / 3$ of all HCC cases. There is a great proportion of patients with $\mathrm{CHB}$ in the end-stage of the disease and the ultimate cure for them is liver transplantation. In a large number of cases, CHB infection is asymptomatic. Liver biopsy and histopathological findings are of utmost importance in the confirmation of 
the diagnosis, disease progression monitoring and assessment of therapy effects.

Due to the course and severe complications of $\mathrm{CHB}$ infection, efforts should be made to eradi- cate HBV infection by mandatory immuniza-tion of all unvaccinated and incompletely vac-cinated persons.

\section{References}

1. Delić D. Hronični virusni hepatitisi. Beograd: Zavod za udžbenike i nastavna sredstva; 2012.

2. Wong SY, Hann HW. Hepatitis B-related hepatocellular carcinoma. OA Hepatology 2013; 1(1):7.

3. Maiwall R, Kumar M. Prevention and treatment of recurrent hepatitis $B$ after liver transplantation. J Clin Transl Hepatol 2016; 4(1):54-65. [CrossRef] [PubMed]

4. Datta S, Chatterjee S, Veer V, Chakravarty R. Molecular biology of the hepatitis $B$ virus for clinicians. J Clin Exp Hepatol 2012; 2(4):353-65. [CrossRef] [PubMed]

5. Kao JH. Molecular epidemiology of hepatitis $B$ virus. Korean J Intern Med 2011; 26(3):255-61. [CrossRef] [PubMed]

6. Croagh CM, Desmond PV, Bell SJ. Genotypes and viral variants in chronic hepatitis $B$ : A review of epidemiology and clinical relevance. World ] Hepatol 2015; 7(3):289-303. [CrossRef] [PubMed]

7. Pande C, Kumar A, Patra S, Trivedi SS, Dutta AK, Sarin SK. High maternal hepatitis DNA levels but not $\mathrm{HBeAg}$ positivity predicts perinatal transmission of hepatitis B to the newborn. DDW 2008; A252.

8. Navabakhsh B, Mehrabi N, Estakhri A, Mohamadnejad M, Poustchi $H$. Hepatitis B virus infection during pregnancy: transmission and prevention. Middle East J Dig Dis 2011; 3(2):92102. [PubMed]

9. Gentile I, Borgia G. Vertical transmission of hepatitis B virus: challenges and solutions. Int ] Womens Health 2014; 6:605-11. [PubMed]

10. LeFevre ML. Screening for hepatitis B virus infection in nonpregnant adolescents and adults: U.S. Preventive Services Task Force recommendation statement. Ann Intern Med 2014; 161(1):58-66. [CrossRef] [PubMed]

11. Haviari S, Bénet $T$, Saadatian-Elahi M, André P. Vaccination of healthcare workers: A review. Hum Vaccin Immunother 2015; 11(11):2522-37. [CrossRef] [PubMed]

12. Schillie S, Murphy TV, Sawyer M, Ly K, Hughes E, Jiles $R$, et al. CDC guidance for evaluating healthcare personnel for hepatitis $B$ virus protection and for administering postexposure management. MMWR-Morbid Mortal W 2013; 62(RR10):1-19.

13. Chisari FV, Isogawa M, Wieland SF. Pathogenesis of hepatitis B virus infection. Pathol Biol (Paris) 2010; 58(4):258-66. [CrossRef] [PubMed]

14. Shuai Z, Leung MW, He X, Zhang W, Yang G, Leung PS, et al. Adaptive immunity in the liver. Cell Mol
Immunol 2016; 13(3):354-68. [CrossRef] [PubMed]

15. Schuch A, Hoh A, Thimme R. The role of natural killer cells and $\mathrm{CD} 8(+) \mathrm{T}$ cells in hepatitis $\mathrm{B}$ virus infection. Front Immunol 2014; 5:258. [CrossRef] [PubMed]

16. Isogawa $M$, Tanaka $Y$. Immunobiology of hepatitis $B$ virus infection. Hepatol Res 2015; 45(2):179-89. [CrossRef] [PubMed]

17. Terrier B, Cacoub P. Hepatitis B virus, extrahepatic immunologic manifestations and risk of viral reactivation. Rev Med Interne 2011; 32(10):622-7. [CrossRef] [PubMed]

18. Yim HJ, Byun KS, Chang YJ, Suh YS, Yeon JE, Lee $\mathrm{CH}$, et al. Levels of hepatitis $B$ virus (HBV) replication during the nonreplicative phase: HBV quantification by real-time PCR in Korea. Dig Dis Sci 2007; 52(9):2403-9. [CrossRef] [PubMed]

19. Yang $\mathrm{HC}$, Kao JH. Persistence of hepatitis $B$ virus covalently closed circular DNA in hepatocytes: molecular mechanisms and clinical significance. Emerg Microbes Infect 2014; 3(9):e64. [CrossRef] [PubMed]

20. Reaiche GY, Le Mire MF, Mason WS, Jilbert AR. The persistence in the liver of residual duck hepatitis $B$ virus covalently closed circular DNA is not dependent upon new viral DNA synthesis. Virology 2010; 406(2):286-92. [CrossRef] [PubMed]

21. Chen JD, Yang HI, Iloeje UH, You SL, Lu SN, Wang LY, et al. Carriers of inactive hepatitis $B$ virus are still at risk for hepatocellular carcinoma and liverrelated death. Gastroenterology 2010; 138(5):1747-54. [CrossRef] [PubMed]

22. Brunetto $M R$, Oliveri $F$, Colombatto $P$, Moriconi $F$, Ciccorossi P, Coco B, et al. Hepatitis B surface antigen serum levels help to distinguish active from inactive hepatitis $B$ virus genotype $D$ carriers. Gastroenterology 2010; 139(2):483-90. [CrossRef] [PubMed]

23. Aspinall EJ, Hawkins G, Fraser A, Hutchinson SJ, Goldberg D. Hepatitis B prevention, diagnosis, treatment and care: a review. Occup Med (Lond) 2011; 61(8):531-40. [CrossRef] [PubMed]

24. Su TH, Hsu CS, Chen CL, Liu CH, Huang YW, Tseng $\mathrm{TC}$, et al. Serum hepatitis B surface antigen concentration correlates with HBV DNA level in patients with chronic hepatitis B. Antivir Ther 2010; 15(8):1133-9. [CrossRef] [PubMed]

25. Gao S, Duan ZP, Coffin C. Clinical relevance of hepatitis B virus variants. World J Hepatol 2015; 7(8):1086-96. [CrossRef] [PubMed] 
26. Caligiuri P, Cerruti R, Icardi G, Bruzzone B. Overview of hepatitis $B$ virus mutations and their implications in the management of infection. World J Gastroenterol 2016; 22(1):145-54. [CrossRef] [PubMed]

27. Coppola N, Onorato L, Minichini C, Di Caprio G, Starace M, Sagnelli C, et al. Clinical significance of hepatitis B surface antigen mutants. World J Hepatol 2015; 7(27):2729-39. [CrossRef] [PubMed]

28. Liang TJ. Hepatitis B: the virus and disease. Hepatology 2009; 49(5 Suppl):S13-21. [CrossRef] [PubMed]

29. Wong GL. Prediction of fibrosis progression in chronic viral hepatitis. Clin Mol Hepatol 2014; 20(3):228-36. [CrossRef] [PubMed]

30. Liaw YF. Clinical utility of hepatitis B surface antigen quantitation in patients with chronic hepatitis B: a review. Hepatology 2011; 53(6):2121-9. [CrossRef] [PubMed]

31. Thompson A, Nguyen $T$, Iser $D$, Ayres A, Jackson $K$, Littlejohn $M$, et al. Serum hepatitis B surface antigen and hepatitis $B$ e antigen titers: disease phase influences correlation with viral load and intrahepatic hepatitis B virus markers. Hepatology 2010; 51(6):1933-44. [CrossRef] [PubMed]

32. Tseng TC, Liu CJ, Chen CL, Wang CC, Su TH, Kuo $\mathrm{SF}$, et al. Serum hepatitis B virus-DNA levels correlate with long-term adverse outcomes in spontaneous hepatitis B e antigen seroconverters. J Infect Dis 2012; 205(1):54-63. [CrossRef] [PubMed]

33. Bonino $F$, Piratvisuth $T$, Brunetto MR, Liaw YF. Diagnostic markers of chronic hepatitis $B$ infection and disease. Antivir Ther 2010; 15(3):35-44. [CrossRef] [PubMed]

34. Fiel MI. Pathology of chronic hepatitis $B$ and chronic hepatitis C. Clin Liver Dis 2010; 14(4):555-75. [CrossRef] [PubMed]

35. Liu Y, Zhang L, Zhou JY, Pan J, Hu W, Zhou YH. Clinical and virological characteristics of chronic hepatitis B patients with coexistence of HBsAg and anti-HBs. PLoS One 2016; 11(1):e0146980. [CrossRef] [PubMed]

36. Fiel MI. Histologic scoring systems for chronic liver disease. 2017 July "cited 2017 Sep 5"; Available from: https://www.uptodate.com/contents/histologicscoring-systems-for-chronic-liver-disease
37. Liang $Y$, Jiang J, Su M, Liu Z, Guo W, Huang $X$, et al. Predictors of relapse in chronic hepatitis $B$ after discontinuation of anti-viral therapy. Aliment Pharmacol Ther 2011; 34(3):344-52. [CrossRef] [PubMed]

38. Schmidt WN, Nelson DR, Pawlotsky JM, Sherman KE, Thomas DL, Chung RT. Direct-acting antiviral agents and the path to interferon independence. Clin Gastroenterol Hepatol 2014; 12(5):728-37. [CrossRef] [PubMed]

39. Perrillo R. Benefits and risks of interferon therapy for hepatitis B. Hepatology 2009; 49(5 Suppl):S103-11. [CrossRef] [PubMed]

40. Peng CY. Nucleos(t)ide analogues therapy for chronic hepatitis B in Taiwan: short-term versus long-term. Curr Hepatol Rep 2013; 12(3):181-7. [CrossRef]

41. Janssen $\mathrm{HL}$, van Zonneveld $M$, Senturk $H$, Zeuzem S, Akarca US, Cakaloglu $Y$, et al. Pegylated interferon alfa-2b alone or in combination with lamivudine or $\mathrm{HBeAg}$-positive chronic hepatitis $\mathrm{B}$ : a randomized trial. Lancet 2005; 365(9454):123-9. [CrossRef] [PubMed]

42. Hagiwara $S$, Kudo M, Osaki $Y$, Matsuo $H$, Inuzuka $T$, Matsumoto A, et al. Impact of peginterferon alpha$2 b$ and entecavir hydrate combination therapy on persistent viral suppression in patients with chronic hepatitis B. J Med Virol 2013; 85(6):987-95. [CrossRef] [PubMed]

43. McMahon BJ. Combination of pegylated interferon and tenofovir for hepatitis B treatment: screening and counseling of patients are warranted. Gastroenterology 2016; 150(1):32-4. [CrossRef] [PubMed]

44. Marcellin P, Heathcote EJ, Buti M, Gane E, de Man RA, Krastev Z, et al. Tenofovir disoproxil fumarate versus adefovir dipivoxil for chronic hepatitis $B$. N Engl J Med 2008; 359(23):2442-55. [CrossRef] [PubMed]

45. Romano L, Paladini S, Galli C, Raimondo G, Pollicino $T$, Zanetti AR. Hepatitis B vaccination. Hum Vaccin Immunother 2015; 11(1):53-7. [CrossRef] [PubMed]

46. Gerlich WH. Prophylactic vaccination against hepatitis B: achievements, challenges and perspectives. Med Microbiol Immunol 2015; 204(1):39-55. [CrossRef] [PubMed]

47. Komatsu $H$. Hepatitis $B$ virus: Where do we stand and what is the next step for eradication. World J Gastroenterol 2014; 20(27):8998-9016. [PubMed] 


\title{
HRONIČNI HEPATITIS B
}

\author{
Vanja Ničković ${ }^{1}$, Radoslav Katanić ${ }^{2}$ Nataša Katanić 2 \\ Ilija Kocić
}

\author{
${ }^{1}$ Kliničko-bolnički centar Priština, Gračanica, Laplje selo, Srbija \\ 2Univerzitet u Prištini, Medicinski fakultet, Kosovska Mitrovica, Srbija \\ ${ }^{3}$ Univerzitet u Nišu, Medicinski fakultet, Niš, Srbija \\ Kontakt: Vanja Ničković \\ Bulevar Nemanjića 77/9, Niš, Srbija \\ e-mail: vanja.nickovic@gmail.com
}

Virus hepatitisa B je primarno hepatotropni virus koji je izazivač kako akutnog tako i hroničnog hepatitisa $B$. Primarni hronični hepatitis $B$ je najčešće samoograničavajuća bolest sa kompletnim izlečenjem za 2-3 meseca od početka bolesti. Smatra se da je 2/3 svetske populacije tokom života bilo u kontaktu sa hepatitis B virusom.

Zahvaljujući uvođenju obavezne imunizacije protiv hepatitisa B, učestalost hroničnog hepatitisa $B$ je prema podacima Svetske zdravstvene organizacije u opadanju. Međutim, kod oko 400 miliona ljudi svetske populacije razviće se hronični hepatitis $B$. Činjenica je da godišnje širom sveta umire više od jednog miliona ljudi od hroničnog hepatitisa, ciroze jetre ili hepatocelularnog karcinoma (HCC). To znači da je hronični hepatitis B globalni zdravstveni problem.

Pravovremena dijagnoza i adekvatna terapija značajno usporavaju tok i progresiju hroničnog hepatitisa $\mathrm{B}$.

Acta Medica Medianae 2017;56(4):50-60.

Ključne reči: hepatitis $B$ virus, patogeneza, klinička slika, imunizacija, dijagnoza, terapija, hronični hepatitis $B$ 